\title{
Editorial
}

\section{Decoloniality and Decolonial Education: South Africa and the World}

\section{Rozena Maart \\ ORCID iD: $\underline{\text { https://orcid.org/0000-0002-3829-1523 }}$}

The decision to put together this collection began as an initiative to engage with presenters and participants of the UNISA Decolonial Summer School of 2019 beyond the content that was presented. UNISA, referring to the University of South Africa, was established in 1873 and is South Africa's foremost distance learning university. UNISA is situated in Pretoria in the province of Gauteng, which is one of South Africa's three capital cities where the executive branch of government is located, with over 400,000 registered students, including its international student population that come from 130 countries around the world. UNISA's Decolonial Summer School commenced in 2013 for the first time, under the direction of the School of Humanities, and has thus far run every year except for 2021, due to the restrictions imposed by the COVID-19 pandemic.

This collection is composed of an introduction, seventeen articles by eighteen authors, two opinion pieces, two roundtables by eight authors, two of whom have articles in the collection, three interviews and three book reviews, and as such contain the work of twenty-eight contributors. Critiques of racism, definitions of decolonisation and decoloniality, histories of enslavement, coloniser - colonised relations, the coloniality of language, the colonial teaching practices of empire colonies, Black and racialised bodies as sites of racism and colonisation in the afterlife of apartheid, the recolonised economy, and the European colonial curricula that continue to support such practices, especially in law schools in South Africa, run between and among the work in this collection. Not only are we confronted with the overwhelming critique of colonial pedagogies, we are also confronted with an ongoing critique of teaching and learning practices within the university system that almost all of the contributors draw attention to. Some authors utilise the terms, Black and White when referring to racialised identity, with capitalisation, and some do not - those who write Afrika in its newly adopted form within the 
South African academy, and those who do not. The collection made provision for these choices, with the full knowledge of how named identities and their writtenness differ from one region to the next.

Drawing attention to the local - South Africa - and the various locations within the world - Bhutan, Brazil, Canada, Colombia, Germany, India, Ire-land, Jamaica, Oman, Senegal, the United States of America, the United Kingdom - are not just places where contributors were born or have lived and worked but places where our agency remains active, where we engage with the world, where we challenge the many ways in which colonisation continues to inform how we write, speak, think, imagine, and produce knowledge.

In this collection, we took a broad approach to the study of decolonisation. The collection is composed of varied engagements with decolonisation and decoloniality and is intentionally inclusive of community-based contributions - those outside of the academy, as well as from within it. Students, alumni, activists, and former students play an important role in this collection not only because they are shaping the work that is being carried out in activist communities in South Africa and around the world but because many are student-cum-activists and are, as such, actively involved in communities where dispossession of Indigenous land, forced removals, and forced migration continue to inform the afterlife of apartheid and colonisation.

Strict protocols with the blind-review process were observed throughout, including the work of the editor, which was handled by the editorin-chief. The process is taken very seriously in the South African context and one that secures that a journal maintains its national and international standards of excellence and repute. Because of the length of time that this process took, we decided to open the call to contributors and participants of the UNISA 2020 Summer School (referring to the University of South Africa and hereafter referred to as the school), as some of the 2019 discussions found continuity there too. All forms of collective work require a commitment to see that the process is adhered to in the best possible way. Here, for this collection, the process took longer than expected as the pandemic forced us into isolation without colleagues to rely on for face-to-face dialogue and discussion, administrative and technical support, which we often take for granted and only realise when those services are not available to us, especially when computers and printers crash, malfunction, and we are left helpless, incapable of furthering the work we stored on computers upon which we rely. For students 
who are contributors, this process was more difficult than anyone anticipated as the closure of library facilities impacted access to resources enormously.

The format that has been chosen situates Puleng Segalo's article, as one of the organisers of the school, as the opening article.

Puleng Segalo's, 'Critical Reflections on UNISA's Decolonial Summer School: In Conversation with Rozena Maart', takes us directly into the call to decolonise the university curricula in South Africa. From Segalo's input, we get a sense of why and how the presenters carry out their work with the community of scholars who attended the school. Segalo informs readers on how the Decolonial Summer School began at UNISA, whilst also sharing her reflections on the accomplishments and challenges of the school in a dialogue session with the editor of the collection. The dialogue format was seen as an important shift in the style of the article as it allowed for questions to be put forward and for the two researchers to engage one another. As the opening article in this collection, it gives an overview of the impetus of the school and why it was offered annually with the broad range of participating national and international scholars. Hereafter, the sequence of articles follows a thematic order and are divided into four segments.

The first segment is composed of four articles and features the work of Lewis R. Gordon, Sabine Broeck, Thomas Meagher, and Patrick Bond and Gumani Tshimomola as co-author. The articles in this segment address definitions of colonisation, decolonisation, decoloniality and racism (and their interrelationships) whilst also noting the afterlife of slavery, and what Sabine Broeck terms 'enslavism'. The third article in this segment, by Thomas Meagher, addresses the spirit of seriousness as a problem for decolonial theory, whilst Bond and Tshimomola address the process from recolonisation to decolonisation in the South African economy.

Lewis R. Gordon's article, 'Some Thoughts on Decolonisation, Decoloni-ality, Racism and Challenges of Citizenship in Communities of Learn-ing', situates, from the outset, what he calls the 'metatheoretical debates', a struggle before the struggle, among theorists who not only spend their time differentiating decolonisation from decoloniality but about the location of where these struggles take place. Lewis Gordon takes readers through some of the differences in the arguments of decolonisation, as taken up by scholars of the global South, some of whom have engaged with questions of depen-dency whilst others address anti-Eurocentrism thought. In 
this regard, Gordon foregrounds the work of Samir Amin, Africa's leading political economist, and the work of Peruvian sociologist and humanist thinker, Anîbal Quijano, who developed the phrase, 'coloniality of being'. The world lost both Amin and Quijano in 2018. Gordon is not arguing against poststructuralism. Rather, he is concerned with the kind of poststructuralism, decolonial scholars are engaged with, and whether they produce the knowledge against the Eurocentric paradigm they assert their vehemence to.

Sabine Broeck's article, 'Decolonality and Enslavism', follows on from Gordon's and continues with the focus on enslavement. Histories of enslavement, and what Broeck calls, enslavism - the historical and ongoing practice of structural anti-Blackness - is central to her discussion of decolonisation. Broeck consistently offers a basis for discussion, by asserting that we engage with the afterlife of enslavement. Broeck's focus is on the connection between the concept of decoloniality which she considers critical, and the framework of such practices which, informed by the work of Black feminists in the United States and Bulgarian psychoanalytic scholar, Julia Kristeva, she reads through the abjectorship of Black bodies.

Thomas Meagher's 'The Spirit of Seriousness', is situated in the existential phenomenology of Jean-Paul Sartre and Simone de Beauvoir and unpacks why the spirit of seriousness is important for decolonisation. Meagher tackles philosophical concerns pertaining to decolonisation and unpacks them by drawing on, in addition to the work of Sartre and de Beauvoir, the work of W.E.B du Bois, Lewis Gordon, Sylvia Wynter and Frantz Fanon. Drawing on Hegel, which we see on several occasions in this collection, Meagher situates seriousness as a value - one of bad faith - and offers several examples of how it is utilised. He includes acts of colonisation that are committed in the name of Christianity, civilisation, King and country, where colonisation is treated as a value, as we have seen globally with enslavement as the end-result of such justification.

Patrick Bond and Gumani Tshimomola's 'From Recolonised to Decolonised South African Economics', start their article by asserting that replacing a neocolonial project of financial control by neoliberal forces, with one that represents genuine economic decolonisation has never been more urgent, in South Africa and everywhere. At the time of the \#FeesMustFall protests, students demanded an extra R40 million be added to the annual budget, and their power of protest was sufficient to defeat Treasury neoliberals. The limits of bourgeois nationalism are essentially defined not just by 
its underlying loyalty to the institutional structures inherited from colonialism but also by the belief of colonial elites that capitalism remains valid despite the state of their underlying and impoverished societies. Samir Amin, born of an Egyptian father and French mother, is considered a pioneer of Dependency Theory and World Systems Theory. Amin, however, situates his work within the school of global historical materialism, and his analysis in this regard is key to the articulations put forward by Bond and Tshimomola, when addressing the move from recolonisation to the decolonisation of the South African economy.

The second segment is composed of six articles and focuses on racialised identity, particularly the body as a site of colonisation, and engages with the work of Fanon and Biko, both of whom draw on Hegel. Hegel is key to several articles in this collection especially those by Malick Diagne, Oumar Dia and Rozena Maart. The Black body as a racialised body, along with racialised identities are key themes in this segment and draw out the philosophical and psychoanalytical elements of coloniser-colonised relations vis-a-vis Hegel, by focusing on desire, recognition, the gaze, and the return of the racialised gaze by the recipient. From the body, Dey and Maart open the mouth of the coloniser and unravel how the taste-buds of the coloniser informed the process of colonisation: it was not only the spice route to India or the coffee route to Java but also the clash of the colonisers over food and enslaved cargo as capital, as a social and cultural property of culinary traditions that the coloniser wanted to possess and reap the benefits. The Portuguese, Dutch, Spanish, French, Germans, English, primarily although not exclusively, sought out particular regions to flavour their palate, and return to the slowly emerging empires with what they considered 'exotic' food. This segment then moves to Jade Gibson's article where heterotopias of self are problematised, vis-à-vis Michel Foucault's concept of heterotopias, followed by Danille Arendse's coming to consciousness of her racialised and legalised Coloured identity. It is important to situate the history of Coloured identity in South Africa.

In Malick Diagne's 'The Socialism of Frantz Fanon: A Theory for the Rehabilitation of Subjugated Peoples', engages with the historicity of Fanon's thought that addresses the radicality of the colonised subject and the drive towards freedom. Herein lies the crux of the decolonial project for the colonized. And as Diagne asserts, Fanon's position on socialism is rooted in the fight for the values and culture of the colonised - much like Amílcar 
Cabral had postulated, which only the colonised can take the lead in fighting. What is clear in Diagne's article, is that it is not the imposition of Marxism or the interpretation of socialism based on European notions of exploitation that are important to the decolonial project, but one where the virtue of African life and African survival to the commitment to decolonisation is accentuated, and which Fanon resolutely postulates.

In Oumar Dia's 'Fanon's "The Negro and Hegel" or How to Appropriate the "Miraculous Weapons Found in the Oppressor"?', Dia takes us through the process of how Fanon utilized Hegel's master and slave dialectics to produce a theory of liberation. Dia relies on the work of Alexandre Kojève, known worldwide for his ground-breaking lectures on German philosopher Hegel. Kojève's interpretation of Hegel's master-slave dialectic had an enormous influence on Jacques Lacan, Maurice MerleauPonty, Georges Bataille, Michel Foucault, Jacques Derrida, and later, on Black Consciousness ideologues and revolutionaries such as Frantz Fanon and Bantu Stephen Biko who envisaged theories of liberation. Dia raises crucial questions about the use of European thinkers in adopting and fashioning theories of liberation from their work. He discusses the reluctance that the colonised have in this regard by noting that the Europe-centric philosopher is often rejected, and notes that this is 'rightly so'.

Rozena Maart's 'Black Bodies on South African Beaches: "Lus" en "Smaak" jou lekkerding', offers a systematic unpacking of the text unleashed by Penny Sparrow - a White South African woman - who along with several others between 2015 and 2016, at the height of the \#FeesMustFall protests, continued to attack Black bodies on social media platforms. Maart borrows from Algerian Jacques Derrida's approach in revealing the hidden, forbidden and repressed within Sparrow's text. Beaches as sites of enjoyment and pleasure for Black bodies, Maart argues, become yet another site for the Hegelian master and slave relationship, which Fanon expounded upon extensively. Maart moves her critique to desire and recognition, injecting the Lacanian jouissance with the Kaaps expressions of lus and smaak, that define, in a limitless way, a particular history of sexuality, pleasure and enjoyment. The reader gets to see a politics of desire that is already present through the history of apartheid, and how the decolonisation of the beach reveals one of the cornerstones of apartheid legislation. Maart draws on Anton Lembede in asserting the qualities of the Black body - as mind, spirit and body that has needs, desires and aspirations whilst also bringing Lacan into the scene of the 
segregated Whites-only beach of Lewis Nkosi's Mating Birds in articulating the transgression of desire, the pinnacle of apartheid legislation.

N. Jade Gibson's, 'Decolonising the "Eye" within the "I" - Heterotopias of Self: An Interdisciplinary Exploration of Visual and Material Relationships among and between Space, Body, Memory, Identity and Place', addresses multifaceted heterotopias. Heterotopia is a world within a world. The world projected by the author and/or artist mimics the world in which she lives by problematising it, disturbing its socio-cultural spaces since the subject of ridicule turns the lens on those who 'other' and by so doing exposes the world they live in for the disjuncture that it causes. Gibson draws our attention to the I and the Eye - a gaze that she encounters and one she recreates, participating in a self-critique and performance of the gaze that is inflicted on her viewer. She returns the gaze by presenting her version of the racialised stereotypes inflicted upon her as she questions under which conditions her physical appearance draws the viewer into a form of ownership of her.

Danille Arendse's "Coloured" Consciousness: Reflecting on How Decoloniality Facilitates Belonging', offers a series of reflections of her Coloured identity from a place of complex existential experiences: she traces these from the place of her birth, early socialisation and education, and then later, as she moves from one province to another upon the completion of her doctoral degree how her understanding of her identity takes on a different shape. Coloured identity is for Arendse, the psychologist-cum-scholar, an imposed legal identity that stems from the period of racial classification in South Africa, which she notes as such, by indicating her choice of expression as 'Coloured' - a term, she addresses as not accepting but which through a series of interactions at the Decolonial Summer School of 2020, forged a path for a deeper engagement as she comes face to face with her decolonial project and comes to grapple with her history of belonging.

Sayan Dey and Rozena Maart's article, 'Decolonisation and Food: The Burden of Colonial Gastronomy - Stories from West Bengal', is a collaborative article, and brings together Dey's work on the food customs of precolonial Bengal and Maart's work on food colonisation from Bengal and Java to District Six, the old slave quarter of Cape Town. Bengali families were enslaved by the Dutch and brought to the Cape to serve as cooks in the middle of the 1650s to work for the food supply of the DEIC's passing ships en route to India. The authors not only link the act of usurpation and ongoing colonisation to the extraction and cargo of enslaved labour but also to the social 
ownership of the means of production, such as culinary skills, expertise and ancestral knowledge of food, as such intellectual property, which the enslaved are not paid for but which the Dutch colonisers relied on and anticipated in advance. Various examples are cited of particular culinary dishes, its preparation, and how colonisation influenced the dishes through ingredients brought from freshly colonised territories into Bengal. Anyone who has a cup of tea and sees the name, Earl Grey or Lady Grey, must know that Britain has never grown tea, or coffee, for that matter, and yet have garnered a reputation for their quaint teashops, which they managed to raise to the level of exquisite, an exercise of elitism borne off the backs of the tea-pickers whose land and culinary histories they stole and continue to take credit for.

The third segment in this collection moves from the Model-C school system in South Africa and into the university setting; it has us paging through the texts that continue to serve as primary reading, in the language of the coloniser, upholding the colonial civilisation of the coloniser despite the government-driven transformation policies and the call to decolonise by students in South Africa and around the world.

Christopher Gevers's article, 'South Africa, International Law and "Decolonisation"', takes us back to 1962, to the opening of Ghana's Law school where Nkrumah made the opening speech. Gevers is one of South Africa's emerging law scholars, and his participation in projects hosted at UKZN, such as 'Critical Times, Critical Race', and 'Race, Space and the City', fostered a platform for his work to be brought to our attention and also for students and scholars to experience the depth and richness of his analysis as a legal scholar challenging the law academy to interrogate their reliance on schools of thought that does not propel South Africa - a country at the tip of the African continent - into the international arena but maintains the links of coloniality through its teaching practices and choice of outdated curricula. Gevers' article asks questions about the absence of 'Third World' law and why they are still truanting outside of the pages of the academy. Gevers also directs readers to African international legal scholarship vis-a-vis the literary foundational works of Chinua Achebe and Ngũgĩ wa Thiong'o.

Sieraaj Francis's article, 'White line-managers and Black labour: Ticking the Boxes of Decolonisation in a Teaching and Learning Unit of a "First Class" University in South Africa', undertakes an interrogation of his refusal to participate in 'decolonial pedagogical practices' as instructed by 
his White line-manager, and the existential journey that ensues. Francis's point of departure is located in the ebb and flow of the university's decolonisation agenda, steered in his view by colonisers who have not questioned their lived experience and as such perpetuate the very racism they claim to be against. Francis's article started as a letter, detailing how he was treated, which he terms a 'less-than' by a White woman line-manager and grew into a historical unpacking of all of the ways in which his multi-dimensional Coloured, Cape Malay, Muslim and Black identity was under attack at this place of work, which he does not name not out of fear but as a means of not drawing attention to one university in South Africa as he believes that racism is rampant everywhere in South African universities. Francis's article offers readers an analysis of the dynamics of racism he experienced in the 'Teaching-andLearning setting where his curriculum vitae was overlooked but the stereotype of his racialised identity treated as his vitae, which meant that he was not afforded the tasks consistent with a person who went to an ivy-league university in the United States but one that by virtue of this racialisation afforded the gazer the benefit of treating him like an uninformed technician.

Juan Ignacio Solis-Arias's article, 'Acts and Actors: Decolonising the study of Architecture at a South African University', begins with the author's location as a foreigner from Colombia in South Africa, and within the university setting where he works within the school of architecture, which forms part of a large structure of the School of Built Environment and Development Studies. At first, using an existential approach, Solis-Arias informs readers of his own racialisation in Colombia and how this informed the way in which he entered South Africa. The racialisation that he speaks of, could easily have been anyway; colonised peoples from around the globe show evidence of internalised racism towards themselves and their loved ones, in similar ways, with hierarchies of skin colour playing a crucial role in how they are able to love and shame simultaneously. Solis-Arias offers an account of his place within the setting that he is unfamiliar but quickly observes that the East African architects who enter the university premises as examiners have come equipped to dehumanise the last of the continent's Black students who dared to enter into the domain of architecture - previously reserved for their colonisers.

Philile Langa, in her article, 'Rainbow Schooling Pains: An AutoEthnographic account of Model C Schooling in South Africa: In Dialogue with Rozena Maart', offers an existential account of her schooling years 
within the Model-C school system. The author considers herself a political experiment: someone who went to a Model $\mathrm{C}$ school, which is a structure that emerged after the formal end of apartheid (1990), with the idea that Black learners would need to be educated by White teachers as a means to address previous inequalities. The notion of imitating White speech, White thoughts and ideas also meant the denunciation of African languages, African cultures and African identity. Langa's article offers an analysis of her decolonial project, which also asks questions about Black presence and the absence of Black teachers as disseminators of Black knowledge.

The fourth segment is composed of two articles, by Sukla Chatterjee and Cloris Porto Torquato, and focuses on literature and language. This focus is not one that South Africans or those in the African diaspora can overlook. When Kenyan writer and academic Ngũgĩ wa Thiong'o announced that he would only write in Gikuyu in the mid-1970s and, penned his Decolonising the Mind, he opened up already ongoing discussion in India but probed the possibility for contemporary writers to think critically about our writing practices and the dissemination of the coloniser's mindset. It is to the latter that Cloris Porto Torquata takes us: a tour-de-coloniality-of-languages, as plurality, as she exposes the many facets of coloniality still maintained and reproduced in Brazil, in the name of modern euro-driven civilisation, which has meant a denunciation of the many African and Indigenous communities of Brazil.

Sukla Chatterjee's 'Redrawing Dystopian Borders: A Decolonial Reading of Vernacular Dystopias through Mahasweta Debi's Short Stories', brings us into the realm of literary dystopias, which is not only on the decolonial agenda in South Africa and in India but across the globe. Starting with Chatterjee's choice of asserting the Bengali spelling of Mahasweta Debi's Bengali identity, and the pronunciation and writtenness of her surname, as Debi, Chatterjee brings the canon of dystopia out of its elitist status and into the world of postcolonial and vernacular Indian literature, which the current decolonial agenda in India, among a handful of scholars, has pushed to the fore. Chatterjee asserts that vernacular dystopias have been the outcome of fears and anxieties, as well as the production of apocalypse scenarios that further entrench the gentryfication and regentrification processes, thereby neglecting to address how gentrification reproduces the very inequalities that writers of vernacular dystopias are against.

Cloris Porto Torquato's article, 'Challenging the Coloniality of Languages', is focused on a teacher's education as a site through which to 
challenge the coloniality of languages, which she addresses as plurality, from the context of Brazil, where she is located. Porto Torquato draws on Fanon, Ngũgĩ wa Thiong'o, Bakhtin, Ta-Nehisi Coates and a range of authors, to challenge the coloniality of languages in Brazil, where Portuguese continues to be treated as the main and only language of speech, knowledge production and knowledge dissemination. Porto Torquato is interested in the social and cultural production of knowledge and the limitations that are imposed by the Brazilian government's insistence in continuing a legacy of coloniality long after the coloniser has left, and which continues to have implications for a population, especially those racialised by the cruelty of divide-and-conquer identity politics.

Following the articles, the collection shifts to two opinion pieces, the first by Sipho Singiswa and the second by Gillian Schutte.

Sipho Singiswa, 'White Arrogance Tramples Mandela's Legacy for African Self-Determination', addresses the inhumane treatment of Indige-nous peoples of South Africa by White colonials. Singiswa also likens White liberals to Mahatma Gandhi, who in his view was considered a leader yet had no regard for Black people or Indigenous peoples of South Africa. Singiswa is not the only person who holds this view; Gandhi has been outed as a racist and casteist by South Africans and Indians in his homeland and across the African and Indian diaspora. Singiswa offers insight into the fallacy of the Mandela presidency, noting that the masses were duped into believing that self-determination and dignity would be restored after apartheid.

Gillian Schutte's, 'The Fallists and White Male Hegemony' situates the actions of the Fallists as central to her critique of White hegemony in South Africa. Schutte is well-known for her critiques of White South Africans, which she argues are only interested in maintaining apartheid-style White privilege for their exclusive benefit. Schutte argues that the Fallist movement shook the White status quo in South Africa and created a paranoia, which fostered a crisis mode reaction among those who occupy and seek to maintain their occupancy of White bourgeois democracy, a delusion that White men, in particular, she notes, care to cultivate. This is despite the generation of young students who forge ahead with the decolonisation agenda, whether White South Africans approve of their actions or not.

Hereafter, the collection proceeds with two roundtable discussions. 
The first roundtable is composed of four contributors all of whom form part of the research group called, 'Race, Space and the City'. Nandipha Makhaye, Nompumelelo Kubheka and Londiwe Sokhabase were students in Archi-tecture when the group started in 2013, and Rozena Maart, who facilitated this roundtable, was then the Director of the Centre for Critical Research on Race and Identity (CCRRI). The research group was established as a consequence of one of the three women in the group questioning the absence of African identity in their education and training as architects at the University of KwaZulu-Natal, for which she was chastised. The three women as architects in this discussion were in the same year of study, each encountering similar experiences of racism such as shunning, ostracization, punishment for speaking out, and public humiliation for their refusal to participate in colonial practices that have continued to be part of the architecture academic environment. In joining the seminars at CCRRI and engaging with students who were part of 'Critical Times, Critical Race', students who were interested in the built environment, were also able to engage their peers on these inter-relationships of land, space and African identity.

The second roundtable is composed of the contributions of five panellists and bring a particular point of view to this collection - they form part of a research group called, 'Critical Times, Critical Race', which emerged in 2013 at the University of KwaZulu-Natal's Centre for Critical Research on Race and Identity (CCRRI): Philile Langa, Ayanda Ndlovu, Phezu Ntetha and Jackie Shandu, share the round-table, chaired by Rozena Maart. When the research group was established all the participants were students. Most have remained students for the past seven years whilst also being involved in various activist work. Ayanda Ndlovu reminded us recently of the activism surrounding \#KingGeorgeMustFall in 2014 at Howard College at a time when the statue of Cecil John Rhodes at the University of Cape Town had not made the news. King George V was the King of the United Kingdom and its dominions from 1936 until 1952. As such, he was the last emperor of India until the partition between Pakistan and India in August 1947. The University of KwaZulu- Natal's Howard College campus where students and alumni in this collection enter, is located on the former King George V drive. The Howard College campus has a King George V statue on display as a reminder of his status as a British imperial and also his position in Natal, as the province was previously called, as the last bastion of the British empire. It is twenty- 
seven years after 1994, and our sites of education are still named after these colonisers, the arches that we walk under, flawlessly marbled with the names of colonials who fought in the First World War, sculpted into the fabric of the building, amid the glisten of the violence which remain absent on their breath but very present above our heads.

The final component of the collection has three interviews and three book reviews: Sabine Broeck's Gender and the Abjection of Blackness, Jane Anna Gordon' third single-authored book, Statelessness and Contemporary Enslavement, and Leonard Harris's A Philosophy of Struggle: the Leonard Harris Reader, edited by Lee A. McBride III. What makes this segment so important is that so many of the contributors in this collection have been influenced by Broeck, Jane Anna Gordon and Leonard Harris. The work on enslavement carries links to all of the three scholars, and whilst there are distinct paths that each of them focus on, they each offer a unique contribution to the growing dearth of decolonial studies intent on examining the previously neglected histories of enslavement, and statelessness, which Broeck and Jane Anna Gordon argue with depth and effortless persuasion. Leonard Harris's work in the ground-breaking formation of Philosophy Born of Struggle as an annual conference that has drawn an international community of scholars, and the collections that he has produced under the same name, for more than three decades, stand as a mark of resilience in a world where philosophy's White mythology, hides behind its inability to articulate a philosophy of justice and a philosophy that brought the history of the masses into the classroom because Harris dared to persevere.

Rozena Maart Associate Professor Gender Studies, Social Sciences University of KwaZulu-Natal Durban, South Africa International Research Ambassador University of Bremen

Germany rozmaart@gmail.com 